\title{
Заштита старе и ретке писане грађе у случају ратних опасности
}

\author{
Вања Ерор \\ Универзитет у Београду \\ Правни факултет - Библиотека \\ vanja@ius.bg.ac.rs
}

\begin{abstract}
Сажетак
У раду су обрађени правни прописи који се баве заштитом старе и ретке писане грађе током ратова, на којима се интензивније ради од друге половине 19. и почетком 20. века. Међународне конвенције, донете у Хагу 1899. и 1907. године, као део међународног ратног права, први су документи који као предмет заштите од ратних дејстава наводе културна добра. Велика разарања у ратовима широм света, уништавање и крађе културних добара у Првом, а потом и у Другом светском рату утицали су да се озбиљно приступи међународној заштити културних добара. Један од предмета заштите су и старе и ретке књиге као покретно културно добро. Кроз низ одржаних међународних конференција донете су уредбе, декларације, конвенције, правилници, како у свету и Европи, тако и у Србији, како би се на најбољи начин заштитила стара и ретка књига и културна добра у целини.
\end{abstract}

Кључне речи: стара и ретка књига, културна добра, правна заштита, непосредна ратна опасност, оружани сукоби

Увод

Старом и ретком књигом сматрају се све оне књиге за које постоји интересовање и које су тешко доступне захваљујући различитим факторима, као што су: датум настанка, историјски значај или важност аутора, број примерака у којем су публиковане или сачуване, а представљају део културне баштине одређене земље. Посебним их чине и специјалан начин и услови њиховог чувања, што је уређено законима ${ }^{1}$ и подзаконским актима.

Питањима заштите старе и ретке књиге одувек се придаје важност, иако се мора истаћи да су се она дуго односила само на преповез књига, конзервацију и рестаурацију. Тек шездесетих година прошлог века у свету је спроведено неколико значајних истраживања о њиховој заштити. Крајем 20. и почетком 21. века долази до промена, јер се заштити старе и ретке књиге приступа озбиљније и спроводи се низ разноврсних активности, чему нарочито доприносе национални планови заштите и дигитализација културне баштине.

\section{Заштита старих и ретких књига у оружаним сукобима}

Питању заштите старе и ретке писане грађе и културних добара у целини у непосредној ратној опасности и рату није се, ни у свету ни код нас, поклањало довољно пажње. Тек након великих ратних разарања у Првом, а потом и у Другом светском рату, када је огроман број културних добара нестао или уништен, приступило се системским мерама заштите.

Прве кораке у заштити културних добара у оружаним сукобима, за време Грађанског рата у Сједињеним Америчким Државама, предузео је Франсис Либер (Francis Lieber),

1 „Закон о старој и реткој библиотечкој грађи Републике Србије“, Службени іласник РС 52 (2011): 3. 
професор на Колумбија универзитету. Он је помагао генералу армије Уније, Хенрију Вагер Халеку (Henry Wager Hallecku) у дефинисању герилског ратовања. На његов захтев, Либер је припремио Предлог правила понашања ратом захваћених држава - Либеров код (Liber Code), ${ }^{2}$ који је усвојен 1863. године, с циљем да се регулише понашање снага Уније у Америчком грађанском рату.

Овај документ садржи 157 чланова, а чланови од 34. до 36. односе се на заштиту културних добара (иако је овај термин у том периоду још увек био непознат). Пошло се од чињенице да поједини објекти, односно имовина која припада црквама, болницама, школама, музејима или другим установама које имају хуманитарни или образовно-научни карактер, не смеју бити уништени од стране непријатељских снага. Осим тога, предвиђено је да победничке државе могу наредити заплену уметничких дела, научних збирки, библиотека или прецизних инструмената из покорених држава, али се при томе они не смеју оштетити. Питање коначног власништва требало је да буде регулисано мировним уговором. Посебно се истиче да ни у једном случају не може доћи до продаје, уступања, уништења или оштећења наведених добара. ${ }^{3}$

Следећи покушај правног регулисања културних добара представља међународна конференција која је, на иницијативу руске Владе, односно руског цара Александра II, одржана у Бриселу 1874. године. На њој је учествовало 15 држава, када је донета Бриселска декларација (Декларација о законима и обичајима рата), ${ }^{4}$ која није никада усвојена због отпора Велике Британије. Члан 8, од укупно 56, посвећен је овој области и, највероватније по угледу на Liber Code, одређује да имовина религијских, хуманитарних, образовних, научних или уметничких установа, иако припада држави, треба да буде третирана као приватна имовина. За сваку заплену, уништење или вољно оштећење таквих установа, као и историјских споменика или деิла уметности и науке, надлежне власти ће гонити починиоце. ${ }^{5}$ Угледни Институт за међународно право (Гент, Белгија) ${ }^{6} 1880$. године, укључује одредбу сличну наведеном члану из Бриселске декларације у свој Приручник о законима и обичајима pā̄a. ${ }^{7}$

Сви покушаји да се утврде правила која би била обавезујућа и која би поштовао већи број држава, са жаљењем се мора констатовати, нису успели. Оно што се истиче у овим покушајима јесу напори да се издвоји „одређена“ имовина. Она није дефинисана као добро од културног значаја, већ се најчешће врши пуко набрајање ресурса који су у својини државе и припадају категоријама које би требало да имају знатно већу заштиту (тако што ће бити обележени заставом за примирје и амблемом Црвеног крста) и понекад се изричито забрањује заплена или њихово уништење.

Значајнији развој правне регулативе о заштити културних добара уочава се крајем 19. и почетком 20. века.

На иницијативу руског цара Николаја II, 1889. године, у периоду од 18. маја до 29. јуна, на Првој хашкој мировној конференцији, састали су се делегати 26 држава како би расправљали о питањима рата и мира. Главни циљ Конференције био је стварање услова за спречавање ратова и одржавање трајног мира. На овој значајној међународној

\footnotetext{
2 Instructions for the Government of Armies of the United States in the Field (Lieber Code), 24 April 1863, https://ihl-databases.icrc.org/ ihl/INTRO/110 (preuzeto 21. 12. 2016).

${ }^{3}$ Ibid.

${ }^{4}$ Project of an International Declaration concerning the Laws and Customs of War. Brussels (27 August 1874), https://ihl-databases.icrc.org/ ihl/INTRO/135 (preuzeto 9. 2. 2018).

${ }^{5}$ John Henry Merryman, "Two ways of thinking about cultural property", American Journal of international law 4 (1986): 834.

${ }^{6}$ Institut de Droit International (Ghent, Belgium).

The Laws of War on Land (Oxford, 9 September 1880), https://ihl-databases.icrc.org/ihl/INTRO/140?OpenDocument (preuzeto 9.2 2018).
} 
конференцији усвојен је низ конвенција, ${ }^{8}$ којима је, између осталог, уређена заштита културних добара у рату.

Преласком у 20. век нагло се појачало интересовање за ову област, нарочито на међународном плану. Све се више учвршћује став да је неопходно да се обезбеди заштита културних добара од ратних разарања.

Године 1907, на иницијативу САД и Русије, сазвана је друга конференција у Хагу, која је, окупила 44 државе. На њој је усвојена Конвенција о законима и обичајима рата на копну, ${ }^{9}$ у чијем су се Правилнику нашли и принципи претходних конвенција из 1889. године.

Хашке Конвенције о законима и обичајима рата на копну из 1899. и 1907. године биле су усмерене ка стварању правила зараћених страна и њиховим односом током ратова. ${ }^{10} У$ домену заштите културних добара, међу којима и старе и ретке библиотечке грађе, истичу се чланови 27. и 56. који се баве заштитом богослужбених, уметничких и добротворних институција, као и историјских споменика, постављајући основе за посебан однос према заштити културне баштине у ратним условима. Чланом 27. строго се забрањује агресорима намерно разарање ових објеката и забрањује се њихова употреба у било какве војне сврхе, ${ }^{11}$ док се члан 56. бави третманом културних добара на окупираним подручјима, односно претпоставља судско гоњење у случају заплене, разарања, намерног уништавања или оштећивања историјских споменика, уметничких и научних дела, ${ }^{12}$ уводећи по први пут елементе санкционисања у заштити културних добара.

Страхоте Првог и Другог светског рата, у којима је у великој мери страдало и културно наслеђе, довеле су до усвајања савремених међународних уговора о његовој заштити.

По окончању Првог светског рата, за време Париске конференције 1919. године, основано је Друштво народа, или Лига народа, као међународна организација са основним циљевима: разоружање, спречавање рата преко колективне безбедности, решавање размирица између земаља путем преговарачке дипломатије и побољшање глобалног благостања. И у оквиру Друштва народа чињени су напори на плану заштите културних добара током ратова. Под окриљем ове организације, 1939. године, владе Белгије, Шпаније, САД, Грчке и Холандије сачиниле су предлог Конвенције о заштити споменика и уметничких дела у време рата. ${ }^{13}$ Међутим, ти напори осујећени су почетком Другог светског рата, који је донео промене у техничким достигнућима, тактици и стратегији ратовања, као и нови концепт тоталног рата.

\section{Конвенција о заштити културних добара у случају оружаног сукоба из 1954. године}

Како је током Другог светског рата уништавање писаних докумената достигло огромне размере, одмах по окончању сукоба иницирано је формирање организације која би се бавила заштитом културних добара, како покретних, тако и непокретних, у случају рата. Започета

\footnotetext{
${ }^{8}$ То су: Конвенција о законима и обичајима рата на копну, 2) Конвенција о примени начела Женевске конвенције од 22. августа 1864. године о положају рањеника у рату на рањенике у поморским ратовима и 3) Конвенција о мирним начинима решавања међународних спорова. Овом приликом су донете и три декларације: 1) Декларација о забрани бацања пројектила и експлозива из балона и сличних направа, 2) Декларација о загушљивим гасовима и 3) Декларација о забрани употребе распрскавајућих (дум-дум) метака.

${ }^{9}$ Convention (IV) respecting the Laws and Customs of War on Land and its annex: Regulations concerning the Laws and Customs of War on Land (The Hague, 18 October 1907), https://ihl-databases.icrc.org/ihl/INTRO/195 (preuzeto 9. 2. 2018).

10 "Konvencija (IV.) o zakonima i običajima rata na kopnu - 1907“ (član 5. preambule), Zakonitost 46 br. 1-2 (1992): 39

11 Ibid, čl. 27: 47

12 Ibid, čl. 56: 51

${ }^{13}$ Marcel Deltenre, Recueil général des lois et coutumes de la guerre terrestre, maritime, sous-marine et aérienne d'après les actes élaborés par les conférences internationales depuis $1856=$ Algemeene verzameling van de wetten en gebruiken van den oorlog $=$ Allg. Sammlung d. Gesetze und Gebräuche d. Krieges = General collection of the laws and customs of war (Bruxelles: Wellens-Pay, 1943), 755-759.
} 
је кодификација, те је 1954. године у Хагу потписана Конвенција о заштити добара културе у случају оружаног сукоба. ${ }^{14}$ Овом Конвенцијом прописано је да ће државе, предузимајући мере које сматрају примереним, још у време мира, припремити чување културних добара на властитом простору од предвидивих последица оружаног сукоба. Такође је забрањено коришћење културних добара и њихове непосредне околине у сврху самоодбране, којом би она могла бити изложена уништењу или оштећењу. С тим у вези, државе су обавезне да забране, спрече и, према потреби, зауставе сваки облик крађе, пљачке и отуђења културних добара, као и свако вандалско дело усмерено према њима. Истим документом предвиђено је и да покретна културна добра не подлежу реквизицији или репресији.

Конвенција предвиђа заштиту културних добара на два нивоа. У мирнодопским условима неопходно је војним правилницима и инструкцијама обезбедити обуку војних снага како би се поштовала културна добра и свог и других народа. ${ }^{15}$ Када је реч о посебно значајним кутурним добрима, за њих је неопходно испунити још неке услове: архивске зграде у којима се налази грађа морају бити ојачане како би се појачала изолација архивског градива од подручја снажне енергије која се ослобађа у оружаним сукобима. Такође је потребно обавити евакуацију и смештање у склониште збирки и делова збирки или копија докумената на другим форматима, што укључује критеријуме за селекцију материјала за заштиту, одређивање склоништа, физички распоред за пресељење и разматрање околности у којима ће поступак почети. ${ }^{16}$

Иако су оружани сукоби највећа претња институцијама које похрањују културна добра, све наведено може бити од значаја и за заштиту од природних катастрофа.

Конвенција о заштити добара културе у случају оружаног сукоба не разрађује одговарајући систем санкција за случајеве кршења њених одредаба, као што није предвиђено ни међународно тело које би преузело кажњавање прекршилаца. И поред истицања да штета нанета културним добрима, ма ком народу она припадала, представља штету културном наслеђу целог човечанства, санкционисање је поверено самим државама потписницама, које одређене мере предузимају у оквиру свог казненог права.

Такође се дефинише и уздржавање од сваког непријатељског акта који би био уперен против ових добара. Међутим, постоји изузетак предвиђен Конвенцијом који је могућ када војна потреба захтева одступање од наведене дефиниције и то: када је културно добро својом функцијом претворено у војни циљ, нема другог стварно могућег решења за постизање сличне војне предности какву пружа усмеравање непријатељског чина према том циљу, или није могућ избор између такве употребе културних добара и некога другог стварно могућег начина за постизање сличне војне предности. Овакве одлуке може донети командант јединице која је по величини једнака дивизији или већа и мора унапред упозорити супротстављену страну "када то околности дозвољавају“. ${ }^{17}$ Тако се може закључити да се оваквом одредбом руши сврха и ауторитет Конвенције, а тиме и многобројни примери уништавања културних добара у оружаним сукобима добијају легитимитет.

Ова Конвенција се примењује у сваком оружаном сукобу, како међународном, тако и у грађанском рату. Државе потписнице су дужне да у своја правила унесу одредбе о заштити и поштовању добара културе, као и да најмање једном сваке четири године пошаљу генералном директору UNESCO-а извештај којим дају обавештење о мерама које су њихове администрације

\footnotetext{
${ }^{14}$ UNESCO, Hague Convention for the Protection of Cultural Property in the Event of Armed Conflict (1954) (Paris, 2010), http//:www.unesco org./culture/laws/hague/1954/montenegro.pdf (preuzeto 28. 12. 2013).

15 Конвенција за заштиту културних добара у случају оружаног сукоба, http://www.kultura.gov.rs/docs/ stranice/82128418889499865927/8.\%20Konvencija\%20za\%20zastitu\%20kulturnih\%20dobara\%20u\%20slucaju\%20oruzanih\%20 sukoba(\%20Hag,\%201954).pdf (преузето 26. 9. 2017).

${ }^{16}$ Axel Plahte, „UNESCO - program hitnih mjera za zaštitu vitalnog gradiva u slučaju oružanih sukoba“, Arhivski vjesnik 43 (2000): 78.

17 Конвенција за заштиту културних добара у случају оружаног сукоба. Члан 11, Одузимање имунитета.
} 
предузеле, припремиле или узеле у разматрање у циљу примене Конвенције. Основни циљ ове обавезе је да се, пре свега, генерални директор упозна са њеном применом у појединим државама, а преко њега, односно публикација које издаје UNESCO, и цела међународна заједница.

Конвенција је ратификована и у бившој Југославији Законом о ратификацији Конвенције за заштиту културних добара у случају оружаног сукоба, који је усвојила Савезна народна скупштина на седници Савезног већа од 28. децембра 1955, а проглашен Указом Председника Републике од 29. 12. 1955. године. ${ }^{18}$ Истим Законом ратификовани су и Правилник за извршење Конвенције за заштиту културних добара у случају оружаног сукоба и Протокол о заштити културних добара у случају оружаног сукоба, који су саставни делови Конвенције.

\section{Развој правне заштите писане грађе у Србији}

Проблеми у вези са заштитом писане грађе у ратним условима, иако су бројни и сложени, веома ретко су били предмет саветовања архивиста и библиотекара, како код нас, тако и у свету. У бившој СФРІ, на Савезном архивском саветовању у Задру 1971. године, први пут је формулисана тема Заштита архивске грађе у рату и непосредној ратној опасности. ${ }^{19}$

Правне основе заштите старе и ретке писане грађе за случај ванредних прилика, непосредних ратних дејстава и рата, у Србији после распада Југославије, темељили су се још увек на умногоме застарелим прописима из области општенародне одбране и друштвене самозаштите, донетим седамдесетих и осамдесетих година 20. века. Мали број архивских и сродних установа у Србији је имао све потребне услове за оптимално функционисање (наменску зграду, склоништа, опрему и др.), ажуриране планове одбране, потребна средства за одбрану у случају рата или ратних дејстава. Тек 1999. године, натеран околностима у којима се нашла земља услед НАТО бомбардовања, законодавац је донео Правилник о мерама заштите културних добара у случају непосредне ратне опасности и рата и Упутство о мерама заштите архивске грађе и рестаураторског материјала у случају рата. ${ }^{20}$ Њима су ближе биле регулисане мере заштите архивске грађе у случају рата и ратних дејстава.

Осим Правилником, заштита старе и ретке библиотечке грађе регулисана је Законом о старој и реткој библиотечкој грађи који под заштитом претпоставља: „проналажење, прикупљање, чување, заштита и коришћење грађе, проучавање и вредновање грађе, категоризација и вођење регистра, обрада грађе и вођење регистра, обрада грађе и израда каталога уз примену одговарајућих међународних стандарда за библиографско-каталошки опис, пружање стручне помоћи сопственицима, обављање стручног надзора, израда стручних упутстава, развој и унапређење стручног рада на њеној заштити, спровођење мера заштите (превентивна заштита, микрофилмовање, дигитализација, конзервација, рестаурација), старање о условима, начину коришћења и представљање грађе, истраживање и издавање научних и стручних публикација о грађи, као и објављивање грађе, обезбеђење доступности грађе и њено представљање домаћој и страној јавности, стручно оспособљавање и усавршавање запослених, израда плана заштите у ванредним околностима, други послови заштите грађе". ${ }^{21}$ Нажалост, мора се констатовати да Закон ниједним својим чланом не предвиђа заштиту у непосредној ратној опасности, иако је познато да су уништавања српске културне баштине, библиотечких фондова и са њима и старе и ретке библиотечке грађе

\footnotetext{
18 „Међународни и други споразуми“, Службени лисше ФНРЈ 4 (додатак) (02. 04. 1956).

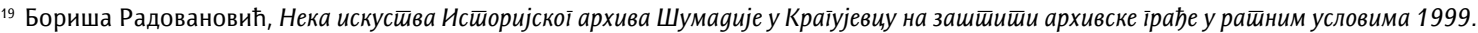
іоgине (Крагујевац: Историјски архив Шумадије, 2010), 233. 
током Првог ${ }^{22}$ и Другог ${ }^{23}$ светског рата биле немерљиве, као и да је Агресијом НАТО пакта на Савезну Републику Југославију 1999. године учињена огромна штета српској културној баштини. Угрожена су или тешко оштећена културна добра српског народа од непроцењиве вредности, па чак и она под заштитом UNESCO-а. ${ }^{24}$

\section{Закључна разматрања}

Механизми правне заштите културних добара су се развили као последица уништавања, нестанка и разарања у оружаним сукобима кроз историју. Интересовање међународне заједнице је настало као последица све већих ратних разарања и немогућности да се културна добра заштите од ратних дејстава. Како су последице оружаних сукоба временом бивале све погубније, повећавало се и интересовање међународне заједнице за њихову заштиту. Најефикаснији начин је, наравно, спровођење конвенција и донетих закона, односно да се на кривце примењују предвиђене санкције. Унапређење легислативе, али и примена постојећих правила у пракси, довели би до тога да штета која произилази из уништавања културних добара буде сведена на минимум.

У данашње време у целом свету се развија свест о неминовности заједничких акција на заштити културне баштине и несумњиво је да међународна заједница, као и саме државе, улажу све веће напоре како би је ефикасно заштитиле. Због свега тога, активности у овој области постају све динамичније.

Без обзира на напоре држава и појединаца, културна добра у оружаним сукобима широм света нису довољно заштићена, што за последицу има немерљиву штету приликом ратних разарања. Осим законских норми, потребно је радити на подизању свести у друштву о значају културних добара своје земље и других држава као дела светске културне баштине.

\footnotetext{
22 Први светски рат донео је огромна разарања културних институција, пљачке и спаљивања музеја, архива, библиотека. Познато је, према документима Генералног војног гувернмана, да су „одговарајуће аустроугарске институције, у договору са врховном армијском командом и пре 1916. године, имале спремне 'високообразоване културне комесаре' задужене за прикупљање старих и ретких књига. Они су, према овим документима, 11. јуна 1916. године имали одобрење 'за сакупљање дневних новина, календара, разгледница, плаката, позивница' и другог материјала у разним научним институтима које је требало упутити у Беч или Сарајево (босанско-херцеговачком Институту за истраживање Балкана)“. Имовина Народне библиотеке из Београда страдала је у бомбардовању, а део фондова је пренет у Ниш, одакле су га Бугари, заједно са књигама и грађом јавне и гимназијске библиотеке у Нишу, пренели у Софију. Овакву или сличну судбину имале су готово све јавне и гимназијске библиотеке широм Србије, док су имовина и фонд Ресавске библиотеке из Свилајнца једним делом спаљени, а остатак бачен у Ресаву. Фондови свих библиотека у Пироту, као и имовина приватних књижара и штампара, изгорели су на ломачи у центру града - Бранка Драгосавац, Јавне библиошеке у Србији оg 1901. gо 1918. (Панчево: Градска библиотека; Ниш: Библиотека „Стеван Сремац“; Неготин: Библиотека "Доситеј Новаковић“, 2016), 119; Светлана Мирчов, Јован Томић: библиошекар и науиник (Београд: Народна библиотека Србије, 2007; Десанка Стаматовић, Ресавска библиошека: og Чишаониие "Омлаgине Ресавске" go gанас: (1868-1998) (Свилајнац: Ресавска библиотека; Центар за културу, 1998), 95; Стојан Јовановић, „О бугарском спаљивању српских књига у Пироту за време окупације: 1915-1918. године“, Пиройски іласник 3 (18. новембар 1918): 2-3.

Међутим, познато је, према истраживањима Елизабете Георгиев, да је било и другачијих примера, односно заштите српске књиге током Првог светског рата. У овом раду истицао се нарочито Стилијан Чилингиров, који је одиграо кључну улогу „у очувању и сређивању заплењених српских књига у Првом светском рату, које су као ратни трофеј достављене Народној библиотеци у Софији. Он је 1915. и 1916. године био члан главне комисије задужене за пријем српских публикација, а касније један од главних стручњака чија дужност је била њихово сређивање и инвентарисање. По завршетку Првог светског рата, Стилијан Чилингиров је, као директор Бугарске народне библиотеке и особа најупућенија у судбину српских књига, био одговоран за њихову примопредају комисији сачињеној од представника Народне библиотеке Србије и француских војних снага, које су спроводиле ове активности." За своје заслуге одликован је орденом Белог орла V степена, „који је добио за спасавање од уништења 70.000 књига Народне библиотеке Србије током Првог светског рата“. (Елизабета Георгиев, "Стилијан Чилингиров и његов допринос очувању српских

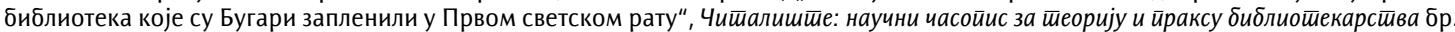
30 (мај 2017): 41-54, http://citaliste.rs/casopis/br30/georgiev_elizabeta.pdf (преузето 9. 2. 2018).

${ }^{23}$ Други светски рат, више и интензивније од претходног, донео је оргомна разарања, а штета која је нанета културним добрима била је немерљива. Страшан културни геноцид у Србији представљало је уништавање Народне библиотеке у Београду, која је била означена као један од првих ратних циљева непријатељске војске. Циљ је био затирање српске културне баштине и брисање колективног памћења. На Библиотеку су 6. априла 1941. године у 16 часова бачене запаљиве бомбе које су до темеља уништиле не само зграду, намештај и опрему, већ и све похрањено писано културно благо које се у њој чувало: књиге и часописе (500.000 свезака), новине, 1390 рукописних књига, од тога 100 на пергаменту, око 2000 писама знаменитих личности, 200 старих књига штампаних до 1800. године, карте и слике, као и разне друге уникате и раритете (архиве, повеље, разна акта и сл.). - Aleksandra Vraneš, „Narodna biblioteka Srbije u ratnim godinama: (1941-1944), http://www.nb.rs/view_file.php?file_id=464 (preuzeto 12. 12. 2016).

24 Здравко Петровић и Наташа Мрвић Петровић, „Правна заштита културних добара у оружаном сукобу“, Избор суgске йраксе 7/ванр. 2 (1999): 18; Гордана Стокић Симончић и Зоран Ч. Вукадиновић, „Српска књига и библиотеке на Косову и Метохији“, Паниевачко иителишие 8, 15 (2009): 52-58.
} 


\section{Литература и извори:}

1. Convention (IV) respecting the Laws and Customs of War on Land and its annex: Regulations concerning the Laws and Customs of War on Land. The Hague, 18 October 1907. https://ihl-databases.icrc.org/ihl/ INTRO/195 (preuzeto 9. 2. 2018).

2. Deltenre, Marcel. Recueil général des lois et coutumes de la guerre terrestre, maritime, sous-marine et aérienne d'après les actes élaborés par les conférences internationales depuis $1856=$ Algemeene verzameling van de wetten en gebruiken van den oorlog = Allg. Sammlung d. Gesetze und Gebrauche d. Krieges = General collection of the laws and customs of war. Bruxelles: Wellens-Pay, 1943.

3. Dragosavac, Branka. Javne biblioteke u Srbiji od 1901. do 1918. Pančevo: Gradska biblioteka; Niš: Biblioteka "Stevan Sremac"; Negotin: Biblioteka „Dositej Novaković", 2016.

4. Georgiev, Elizabeta. "Stilijan Čilingirov i njegov doprinos očuvanju srpskih biblioteka koje su Bugari zaplenili u Prvom svetskom ratu“. Čitalište: naučni časopis za teoriju i praksu bibliotekarstva br. 30 (maj 2017): 41-54. http://citaliste.rs/casopis/br30/georgiev_elizabeta.pdf (preuzeto 9. 2. 2018).

5. Instructions for the Government of Armies of the United States in the Field (Lieber Code). 24 April 1863. https://ihl-databases.icrc.org/ihl/INTRO/110 (preuzeto 21. 12. 2016).

6. Jovanović, Stojan. „O bugarskom spaljivanju srpskih knjiga u Pirotu za vreme okupacije: 1915-1918. godine". Pirotski glasnik 3 (18. novembar 1918): 2-3.

7. „Konvencija (IV.) o zakonima i običajima rata na kopnu - 1907“ (član 5. preambule). Zakonitost 46 br. 1-2 (1992): 39.

8. Konvencija za zaštitu kulturnih dobara u slučaju oružanog sukoba. http://www.kultura.gov.rs/docs/ stranice/82128418889499865927/8.\%20Konvencija\%20za\%20zastitu\%20kulturnih\%20dobara\%20 u\%20slucaju\%20oruzanih\%20sukoba(\%20Hag,\%201954).pdf (preuzeto 26. 9. 2017).

9. "Međunarodni i drugi sporazumi“, Službeni list FNRJ 4 (02. 04. 1956).

10. Merryman, John Henry. "Two ways of thinking about cultural property". American Journal of international law 4 (1986): 831-853.

11. Mirčov, Svetlana. Jovan Tomić: bibliotekar i naučnik. Beograd: Narodna biblioteka Srbije, 2007.

12. Petrović, Zdravko i Nataša Mrvić Petrović. „Pravna zaštita kulturnih dobara u oružanom sukobu“. Izbor sudske prakse 7/vanr. 2 (1999): 18-20.

13. Plahte, Axel. „UNESCO - program hitnih mjera za zaštitu vitalnog gradiva u slučaju oružanih sukoba“. Arhivski vjesnik 43 (2000): 77-90.

14. Project of an International Declaration concerning the Laws and Customs of War. Brussels. 27 August 1874. https://ihl-databases.icrc.org/ihl/INTRO/135 (preuzeto 9. 2. 2018).

15. Radovanović, Boriša. Neka iskustva Istorijskog arhiva Šumadije u Kragujevcu na zaštiti arhivske građe u ratnim uslovima 1999. godine. Kragujevac: Istorijski arhiv Šumadije, 2010.

16. Stamatović, Desanka. Resavska biblioteka: od Čitaonice "Omladine Resavske" do danas: (1868-1998). Svilajnac: Resavska biblioteka; Centar za kulturu,1998.

17. Stokić Simončić, Gordana i Zoran Č. Vukadinović. „Srpska knjiga i biblioteke na Kosovu i Metohiji“. Pančevačko čitalište 8, 15 (2009): 52-58.

18. The Laws of War on Land. Oxford, 9 September 1880. https://ihl-databases.icrc.org/ihl/ INTRO/140?OpenDocument (preuzeto 9. 2. 2018).

19. UNESCO. Hague Convention for the Protection of Cultural Property in the Event of Armed Conflict (1954). Paris, 2010. http//:www.unesco.org./culture/laws/hague/1954/montenegro.pdf (preuzeto 28. 12. 2013).

20. Vraneš, Aleksandra, „Narodna biblioteka Srbije u ratnim godinama: (1941-1944)“. http://www.nb.rs/ view_file.php?file_id=464 (preuzeto 12.12. 2016).

21. „Zakon o staroj i retkoj bibliotečkoj građi Republike Srbije“. Službeni glasnik RS 52 (2011). 
Ерор, В. „Заштита старе и ретке писане грађе у случају ратних опасности“, 83-90

\title{
Protection of Old and Rare Written Materials in Case of War Threats
}

\begin{abstract}
The paper deals with legal regulations on protection of old and rare written materials during wars. Work in this area has been intensified since the second half of the $19^{\text {th }}$ and the early $20^{\text {th }}$ century. The international conventions issued in The Hague in 1899 and 1907, as part of the international law of war, are the first documents citing cultural property as a subject of protection from warfare. Great devastation in wars around the world, destruction and theft of cultural goods in the First, and then in the Second World War, have influenced the serious approach to the international protection of cultural property. Since then, several international conferences have been held and a number of regulations, declarations and conventions have been adopted in the world and in Europe, as well as in Serbia, in order to protect the old and rare books and the cultural heritage as a whole.
\end{abstract}

Keywords: old and rare books, cultural property, legal protection, immediate danger of war, armed conflicts

Примљено: 28. јануара 2018. Исправке рукописа: 13. фебруара 2018. Прихваћено за објављивање: 18. фебруара 2018. 
